\title{
The Prophet Disarmed: Milton and the Quakers
}

\author{
STEVEN MARX
}

"All armed prophets were victorious and the unarmed came to ruin." 1

The question of war or peace troubled sixteenth and seventeenth century Europe as much as it troubles our own time. Organized violence-the systematic infliction of irrevocable harm upon one group of human beings by another-was the activity by which the modern nation-state originated, defined itself, rose and fell. During those centuries, most Europeans affirmed, or at least accepted war as the final arbiter of what happened in history. But a significant minority, whether because of inner illumination, abstract reasoning, or the outcome of experience, disputed the primacy of war, maintaining that organized violence was intrinsically evil and that its purposed benefits rarely outweighed its costs. This debate between war and peace influenced the policies of princes, the exhortations of divines, and the speculations of philosophers as well as the daily thoughts of citizens. It also shaped the imaginative productions of artists and writers throughout the early modern period.

During the sixteenth century, the dispute between militarists and pacifists took place in a largely secular context epitomized by the competing humanisms of Machiavelli and Erasmus. In a recent study, I have shown how Shakespeare dramatized that secular

Steven Marx is Associate Professor of English at Cal Poly University, San Luis Obispo and author of Youth Against Age: Generational Strife in English Poetry (1984). This essay is part of a larger work in progress about militarism and pacifism in English literature. 
debate about war and peace in individual plays and in his own shift of authorial perspective from hawk to dove when the pacifist King James ascended to the throne in $1603 .^{2}$ In the present essay, I will examine the pro- and anti-war debate in the religious context within which warfare was conducted and represented during the later seventeenth century. Rather than worldly contests over wealth, territory, or succession, during this period wars throughout Europe were fought as holy crusades on behalf of God and against Satan. Milton, the prime English poet of this age, chose not to depict the civil wars of England or of Rome but rather the War in Heaven; he chose as his source not Holinshed or Plutarch but rather the Holy Scriptures. I will argue that the war and peace debate in Milton's time governs the structure of two of his major works and reveals a dramatic shift in the poet's point of view over time from a militarist to a pacifist outlook. I will further contend that Milton's views on war and peace closely parallel and eventually converge with those of the Quakers, whose "peace testimony" emerges and defines itself in the course of his career. ${ }^{3}$

Two kinds of objections offset this thesis, one from the right, the other from the left. Many historians and literary scholars insist that there was no significant anti-war sentiment in earlier periods of European culture; that to find any is simply anachronism, a reading of twentieth-century liberal shibboleths into the past. Thus, for example, in Captain or Colonel: The Soldier in Milton's Life and Art (1984), Robert Thomas Fallon attacks earlier claims that Milton criticizes warfare in Paradise Lost:

in the absence of historical evidence I had to question the assumption that the sensibilities of the 1650 s resembled so closely those of the 1960s and that a seventeenth-century Puritan like Milton, whose causes prospered through the force of arms and who was the loyal servant of a military regime for a decade, would share the sentiments of twentieth-century pacifist thought. ${ }^{4}$

Fallon can dismiss two book-length studies-Stella Purce Revard's The War in Heaven: "Paradise Lost" and the Traditions of Satan's Rebellion $(1980)^{5}$ and James A. Freeman's Milton and the Martial Muse: "Paradise Lost" and the European Traditions of War (1980) because neither Revard nor Freeman produces extra-textual evidence of anti-war attitudes in Milton's environment. One purpose of this essay is to bring such evidence to bear on an interpretation of Milton's life and work.

On the other hand, Christopher Hill, whose Milton and the English Revolution (c. 1977) taught me to think about the relation 
of seventeenth-century religious politics to Milton's poetry, acknowledges the presence of Quakers and of pacifism in Milton's political world, but refuses to allow any link between the latter two:

I do not intend to suggest that Milton belonged to any of these groups, that he was a Leveler, a Ranter, a Muggletonian or an early [i.e. pre-pacifist] Quaker. But .... their ideas illuminate his and may well have influenced him, both positively and negatively.

By 1660 Milton would have criticized ... Quakers, on these grounds: they ignored the world as it really is, in all its brutality: they were fundamentally unserious, as self-regarding as a modern hippie.

The picture of Milton subsiding into a genial and pacifist old age, in which all conflicts are mental only, is a piece of twentieth-century sentimentalism which the seventeenth century texts do not justify.

Though I hesitate to challenge Hill's prodigious scholarship, I hope the material I present here will counter some assumptions about Quakers and pacifists that make for inconsistencies in his readings of Paradise Lost and Paradise Regained.

James Stuart's efforts to act as blessed peacemaker ${ }^{8}$ were not popular among the subjects he sought to alert to the horrors of war, particularly not among the Puritans. James's perceived "appeasement" of the Spanish power that had sent the Armada and that was carrying out atrocities in the Netherlands stoked the fires fueled by Puritan preachers. ${ }^{9}$ They demanded not only a more aggressive policy against the Papist enemy, but also a revival of "the dignity of chivalry" to elevate the "extraordinarily low esteem into which soldiers had fallen" in the early seventeenth century. ${ }^{10}$ The militancy of the puritan preachers presented itself more as religious than political: "Above all creatures God loves soldiers ... the condition of the child of God ... is military in this life." ${ }^{11}$ This was a radical change from the orthodox Christian doctrine of the "just war" going back to St. Augustine. Whereas the medieval church and even Luther had seen the purpose of warfare and of the state which conducted it merely as maintenance of order and restoration of the peace, Calvinists believed that war had a positive purpose, and that it did not require the sanction of 
a duly constituted authority for legitimacy. ${ }^{12}$ Abandoning the just war theory in favor of what Roland Bainton has categorized as the outlook of holy war or crusade, they believed battle was the essential condition of both the inner and the outer life of the true Christian: "The Saints receive their commission from the great King, King of Kings, to have a two edged sword in their hands, to execute judgment upon the Heathen, and punishment upon the people; To binde their Kings with chaines, and their Nobles with fetters of iron." ${ }^{13}$ And the most militant of Old Testatment battle cries were repeatedly invoked: "Cursed he that keepeth backe his hand from sheding of blood." 14

The metaphysics of Puritans emphasized not the harmony of God's creation, but original sin and the continuing eschatological battle between the forces of good and evil: "The world is the great field of God, in which Michael and his angels fight against the dragon and his angels." 15 One source of the crusading spirit was the Reformers' emphasis on the Scripture, where in the Hebrew Bible they read of a Lord of Hosts (or armies) rejecting Saul for his failure to exterminate His enemies and rewarding David with military victories over the Philistines, and where in the Christian Bible they read of the triumph of the armies of the saved before the last judgment. Throughout the century, biblical histories and prophecies were conflated with events on the battlefields of Europe by propagandists who turned their opponents, whether king or pope, to Goliath or Antichrist. Another doctrinal source of military fervor was the ancient metaphorical identification of the conscientious individual as an embattled knight struggling against evil in the world and in the self. Although in the previous century, Erasmus had defined the "militis christiani" as a fighter of the spirit not the flesh, Puritans reliteralized the metaphor of Christian soldier.

The Calvinists' adoption of the crusading approach to war had major military consequences. Starting on the continent during the Thirty Years' War, the Protestant generals, Maurice of Nassau and Gustavus Adolphus, introduced the regimentation and austerity of the Reformed churches directly into the army, turning it from an assemblage of individual fighters into a disciplined, uniformed, highly drilled war machine, able to do battle in winter as well as summer, restrained from vices like pillage, rape, smoking, drinking, and masturbation, and dedicated to the common cause by the conviction of their own salvation, whether they won or lost. ${ }^{16}$ The general of the English Parliamentary forces, Oliver Cromwell, employed the crusaders' approach to the organization and strategy of his New Model Army to defeat the poorly organized and less 
motivated Cavalier troops of King Charles I and to bring about a Revolution of the Saints maintained by the instruments of martial law and secret police.

However, some small Reforming sects refused to go along with the military crusade of the English revolution from the beginning. They included Familists, Anabaptists, and Mennonites, whose reading of the Bible convinced them that nonviolence itself was one of the signs of election, that the rest of the world-"the kingdom of the sword"-was irredeemably fallen, and that participation in any form of government of a nation-state was impermissible. But as the revolution proceeded, a new form of pacifism emerged from one of the most militant of Puritan sects, a pacifism which combined a rejection of violence with a commitment to political involvement and social reform. This was the "peace testimony" of the Quakers. ${ }^{17}$

Quakerism received its name from the physical trembling that manifested the visitations of the spirit in its early adherents, followers of George Fox, a Leicestershire shoemaker whose personal experience of Inward Light spurred him to begin preaching the radical Puritan message of the sufficiency of Scripture and conscience. Like John Lilliburne and John Winstanley, leaders of the Levelers and Diggers who themselves eventually became Quakers, Fox had no more use for the rituals of class and gender hierarchy than for those of organized religion. The Quakers refused to doff hats or use respectful modes of address to their social superiors. Organized largely by peasants and laborers, The Society of Friends, as they referred to themselves, spread throughout Britain and North America and reached a membership of about 35,000 by $1660 .^{18}$

Many early Quakers came from the ranks of Cromwell's New Model Army, and, according to Alan Cole, "shared the radical Puritan conviction that it had once been an instrument for the establishment of righteousness on earth. While that army continued to exist, Friends never completely abandoned the hope that it might resume its old role as a 'battle-axe in the hand of the Lord." ${ }^{19}$ But in 1650 , when offered a commission as a captain in Cromwell's militia, Fox's conscience balked: "I told them . . . I knew from whence all wars did rise, from the lust, according to James's doctrine ... I told them I was come into the covenant of peace, which was before wars and strifes were." ${ }^{20}$ When conscripted by authorities as a common soldier a few weeks later, he refused induction and instead went to jail:

Justice Bennet sent the constables to press me for a soldier, seeing I would not accept of a command. I told them I was 
brought off from outward wars. They came down again to give me press-money but I would take none. . . . After a while at night the constables fetched me up again and brought me before the Commissioners, and they said I should go for a soldier, but I told them that I was dead to it. They said I was alive. I told them, "Where envy and hatred are there is confusion." They offered me money twice, but I would not take it. Then they were wroth, and I was committed close prisoner without bail or mainprize. ${ }^{21}$

At first Fox's objection to the use of "carnal weapons" was only intuitive and personal; he made no attempt to persuade his followers to give up the sword and no appeal to argument or Scripture. But in the course of the 1650 s, his and other Quakers' experiences gradually crystallized into the doctrine that those at peace with themselves belonged to a "royal" community which had no use for coercion or physical force. ${ }^{22}$ They started preaching non-violence, particularly to soldiers and sailors, and were often beaten and imprisoned. In 1654 Fox wrote to Cromwell, "My weapons are not carnal but spiritual and 'my kingdom is not of this world', therefore with a carnal weapon I do not fight, but am from those things dead." 23 And Edward Burrow declared to his fellow soldiers: "Your work hath been and may be honorable in its day and season, but he hath a work more honorable to work after you; that is to destroy the kingdom of the devil and the ground of wars."

Quaker pacifism emerged not only from the experience of the Inner Light, however, but also from political disillusionment with the course of the English revolution. After founding a theocratic commonwealth of the saints and beheading the king in 1649, Cromwell discovered that he could govern the nation for whose liberty he had fought only by a military rule which limited the very spiritual and political freedoms for which the saints had gone to war. Quakers like John Audland were outraged: "Force and compusion may make some men conform to that outwardly, which otherwise they would not do, but that is nothing of weight, their hearts are never the better, but are rather worse, and more hypocrites than before ... for it is God alone by His powerful word of life operating in the hearts of people that changeth them." ${ }^{25}$ Nevertheless, the emergent peace testimony was nearly abandoned in 1659, when, after Cromwell's death, reformers again hoped to purify church and state under a revived Parliamentary rule. At first, Fox looked with favor on this government's request for military support from the Quakers. For ten weeks, he remained 
silent and could not reply to Friends who wanted to join the Bristol militia and wrote him for guidance. Finally, he emerged from what he called his "time of darkness" with an unqualified rejection of the outward sword, and from then on he forbade all Quakers to serve in the military. ${ }^{26}$ It is not clear, however, whether his decision was based upon absolute principle or upon his fear that this latest regime suffered from the same defects as the previous one. An analogous fear, in the following year, motivated Parliament itself to call back Charles II and reinstall the Stuarts on the throne.

The Restoration eliminated whatever remaining appeal military pursuits may have held for the Quakers. Charles II prosecuted the regicides and persecuted all those who publicly maintained radical opinions. After an aborted violent attempt by apocalyptic zealots known as the Fifth Monarchy Men to revive the rule of the Saints, repression of the Quakers was intensified. It was then for the first time, that they condemned all use of violence under any circumstances. Fox presented the official Quaker position to King Charles on 21 January 1661 in a pamphlet entitled: "A Declaration from the Harmless and Innocent People of God called Quakers, against all Sedition, Plotters and Fighters in the World: for removing the Ground of Jealousy and Suspicion from Magistrates and People concerning Wars and Fightings." "The royal army," wrote the Quaker William Smith in 1661, "have put up their swords and would have all men saved." "The bloody or Lion's war" was ended and "the Lamb's war" had begun. ${ }^{28}$

But in distancing themselves from the militant radicals by maintaining their loyalty and nonviolence, the Quakers could not avoid Royalist persecution. Unlike other sects, they refused either to go underground or to make their doctrines of primacy of conscience, economic, racial and gender equality, and political democracy conform to the reinstituted regulations of the monarchy. Instead, persecution strengthened their commitment and their organization as they adopted suffering itself as the chief weapon in "the Lamb's war." Preaching a philosophy of toleration as both a protection for themselves and as an expression of respect for their opponents, they attracted members of all classes and parties, and directed their teachings not only to their own sectarian brethren but to the world at large:

Upon every slender pretext such as their own small discontents, or that they judge the present peace they have with their neighbours cannot suit with their grandeur and worldly glory, they sheath their swords in one another's bowels; ruin, 
waste and destroy whole countries; expose to the greatest misery many thousand families; make thousands of widows and ten thousands of orphans; cause the banks to overflow with the blood of those for whom the Lord Jesus shed his precious blood; and spend and destroy many of the good creatures of God. And all this while they pretend to be followers of the lamb-like Jesus, who came not to destroy men's lives but to save them, . . . not to kill, murder, and destroy men; not to hire poor men to run upon and murder one another, merely to satisfy the lust and ambition of great men; they being often times ignorant of the ground of the quarrel, and not having the least occasion of evil or prejudice against those their fellow Christians whom they thus kill; amongst whom not one of a thousand perhaps ever saw one another before. ${ }^{29}$

In tracts like these, during the years following the Restoration, under the leadership of people like Robert Barclay and William Penn, Quakers developed the practice of "speaking truth to power." While they retained faith in the spiritual guidance of the Inner Light, they promoted a secular pacifism that recalls the language of Renaissance Christian humanists like More and Erasmus and anticipates the pragmatic critiques of war formulated by Enlightenment philosophes.

This chronology of the emergence of Quaker pacifism suggests interesting parallels with "the curve of Milton's career." ${ }^{30}$ Plotting that curve on the axes of inner belief and external experience, one finds that like many Quakers, Milton began as a soldier in the Lion's war and ended as a partisan in the Lamb's. Both Milton and the Quakers forged their visions through time in a sequence of enthusiastic victories and disillusioned defeats, a pattern of reversals, redefinitions, and revaluations.

In 1643, as Milton planned his unfinished "Arthuriad" celebrating the British nation as the heroic embodiment of Christian chivalry, he personified the Revolution as Samson awakening: "Methinks I see in my mind a noble and puissant Nation rousing herself like a strong man after sleep, and shaking her invincible locks." ${ }^{31}$ And in 1649, while Burrow and Dewsbury crusaded against the king, Milton as Cromwell's chief propagandist sang the praises of

those faithful and courageous Barons, who lost their lives in the Field, making glorious Warr against Tyrants for the common Liberty. ... But now, with a besotted and degenerate 
baseness of spirit ... the rest, imbastardiz'd from the ancient nobleness of thir Ancestors, are ready to fall flatt and give adoration to the Image and Memory of this Man [Charles I]. ${ }^{32}$

By 1652, when Fox himself would no longer take up the sword, though would not yet dissuade others, Milton showed similar ambivalence:

Cromwell, our chief of men, who

on the neck of crowned Fortune proud

Hast rear'd God's Trophies ...

While Darwen stream with blood of Scots imbru'd, And Dunbar field resounds thy praises loud, yet much remains

To conquer still; peace hath her victories

No less renown'd than war, new foes arise

Threat'ning to bind our souls with secular chains. ${ }^{33}$

Ambivalence turned to regret during the later years of the Protectorate. After the revolution of the Saints split up into rival factions and Cromwell dissolved Parliament to have himself crowned in a regal ceremony, and while the Quakers objected to the Lord Protector's suppression of Nonconformists, Milton began working on Paradise Lost. As its title suggests, the poem chronicles a series of defeats and disillusionments. Perhaps the most prominent of all of its losses is faith in a military-heroic ethos.

The work opens with the failure of Satan's armed rebellion. Nevertheless, in books 1 and 2, the fallen angel appears as a courageous general who gains more of the readers' sympathies than do his royal opponents, God and the Son. His epic virtuesAchillean strength and Ulyssean guile-are glorified in a setting where war is the ruling principle, both in the governing process of the Great Consult and in the ground of being:

a dark

Illimitable Ocean without bound,

Without dimension, where length, breadth, and highth, And time and place are lost; where eldest Night

And Chaos, Ancestors of Nature, hold

Eternal Anarchy, amidst the noise

Of endless wars, and by confusion stand.

For hot, cold, moist and dry, four Champions fierce

Strive here for Maistry, and to Battle bring 
Thir embryon Atoms; they around the flag Of each his Faction, in thir several Clans Light-arm'd or heavy, sharp, smooth, swift or slow, Swarm populous.

And yet though Satan seems to embody the heroic glory of "Cromwell our chief of men," the suspicious reader notices that he has a tendency to lie whenever he speaks.

The account of the war in heaven, which concludes the first half of Paradise Lost, begins with the expression of martial enthusiasm on both sides. Satan rallies his troops with the traditional hero's vaunt of self-creation in battle:

We know no time when we were not as now;

Know none before us, self-begot, self-rais'd

By our own quick'ning power ...

Our puissance is our own; our own right hand

Shall teach us highest deeds, by proof to try

Who is our equal.

And God sends out his troops with the assurance that their deeds on the field will make righteousness triumphant:

subdue

By force, who reason for thir Law refuse,

lead forth my armed Saints

By Thousands and by Millions rang'd for fight;

them with Fire and hostile Arms

Fearless assault, and to the brow of Heav'n

Pursuing drive them out.

In the heat of battle, before striking his opponent on the head, Abdiel repeats the claim that arms can make reason triumph:

nor is it aught but just

That he who in debate of Truth hath won,

Should win in Arms, in both disputes alike

Victor; though brutish that contest and foul, 
When Reason hath to deal with force, yet so Most reason is that Reason overcome.

But despite these justifications for fighting and despite the fact that God's forces enjoy the benefit of New Model Army discipline'th' inviolable Saints / In Cubic Phalanx firm advanc'd entire, / Invulnerable, impenetrably arm'd: / Such high advantages thir innocence / Gave them above thir foes"(398-402)-neither army achieves its objective, and after two days the holy war turns into a chaotic melee that threatens to turn heaven itself into a no-man's land. And though Satan's defeat might still be read as a resounding victory of the saints, it is not achieved by the highly disciplined military tactics or the innovative armaments mobilized on both sides, but rather by the Son's sole deployment of a superweapon beyond the reach of the forces of evil or of good.

After 1658, Milton's veiled regret about Cromwell shifts to guarded hostility. During the brief interlude of republican rule following the Protector's death and his heir's abdication, Milton addressed the revived Rump Parliament as "recoverers of our liberty . . . after a short but scandalous night of interruption." ${ }^{34}$ And after Book 6, Satan loses his attractiveness altogether and turns from a hero into a sadistic burglar, a voyeuristic toad, and a lounge-lizardlike serpent. As Fox arrives at a conclusive rejection of the Lion's war, in the second half of Paradise Lost, Milton fully repudiates military heroics-not only those of classical epic and medieval romance but also those of the earlier books of the poem:

Not sedulous by Nature to indite

Wars, hitherto the only Argument

Heroic deem'd, chief maistry to dissect

With long and tedious havoc fabl'd Knights

In Battles feign'd ...

Or tilting Furniture, emblazon'd Shields, Impreses quaint, Caparisons and Steeds, Bases and tinsel Trappings, gorgeous Knights At joust and Tournament; ... .

Not that which justly gives Heroic name

To Person or to Poem. Mee of these

Nor skill'd nor studious. 
In Books 11 and 12, while revealing the future of his descendants to an Adam chastened by sin and death, Raphael delivers a sermon condemning the martial values of the heroic age:

For in those days Might only shall be admir'd, And Valor and Heroic Virtue call'd;

To overcome in Battle, and subdue

Nations, and bring home spoils with infinite

Man-slaughter, shall be held the highest pitch

Of human Glory. . .

Thus Fame shall be achiev'd, renown on Earth

And what most merits fame in silence hid.

$(11: 689-699)$

And later, Raphael refuses to celebrate the military victories of the Lord of Hosts and His generals from Moses to Solomon: "and at length they come, / Conducted by his Angel to the Land / Promis'd to Abraham and his Seed: the rest / Were long to tell, how many Battles fought / How many Kings destroy'd, and Kingdoms won" (12:258-62). From the perspective of the second half of Paradise Lost, the glories of triumph celebrated in the Old Testament are themselves reduced to temptations, "the fair appearing good."

After the Restoration of the monarchy in 1660 , the weight of Milton's disillusionment and regret was, like Adam's, increased with external punishment. Blind, bereaved of his second wife, estranged from his daughters, the former Commonwealth Latin Secretary was stripped of his status and his stipend, forced into hiding, arrested and imprisoned for a month, and then released to continue writing his poem:

I Sing with mortal voice, unchang'd

To hoarse or mute, though fall'n on evil days, On evil days though fall'n, and evil tongues; In darkness, and with dangers compast round And solitude.

For the Society of Friends, Charles II's regime also brought on affliction. Friends were beaten, jailed, and prevented from attending the Inns of Court and university. For this reason, in 1662, the young Quaker, Thomas Ellwood, took on the responsibilities of reader to the blind John Milton in return for tutorials in Latin. ${ }^{35}$ 
The blind poet and young student, who would later become a leader of the Society of Friends and edit Fox's journals, were drawn to one another. In 1667 Milton needed to leave the city of London with his family to escape the plague, and Ellwood found him a cottage near his own lodgings in the suburb of Chalfont St. Giles. According to the often quoted passage in his autobiography, when the Quaker ended his latest stint in prison, he visited Milton "to welcome him into the country":

After some common discourses had passed between us, he called for a manuscript of his; which being brought he delivered to me, bidding me take it home with me, and read it at my leisure; and when I had done so, return it to him with my judgement thereupon. When I came home, and set myself to read it, I found it was that excellent poem which he entitled, Paradise Lost. After I had, with the best attention read it through, I made him another visit, and returned him his book, with due acknowledgement of the favour he had done me in communicating it to me. He asked me how I liked it and what I thought of it, which I modestly but freely told him, and after some discourse about it, I pleasantly said to him, "thou hast said much here of Paradise Lost, but what hast thou to say of Paradise Found?" He made no answer, but sat some time in a muse; then brake off that discourse and fell upon another subject. ${ }^{36}$

After the plague passed, Milton returned to London. Ellwood continues:

And when afterwards I went to wait on him there, which I seldom failed of doing whenever my occasions drew me to London, he showed me his second poem, called "Paradise Regained," and in a pleasant tone said to me, "this is owing to you, for you put it into my head by the question you put to me at Chalfont, which before I had not thought of." ${ }^{37}$

Whether or not, as Ellwood claims, it was his influence that stimulated Milton to write Paradise Regained, the curve of pacifist thought that Milton shared with the Quakers reached its terminus in this final work. ${ }^{38}$

Paradise Regained is something of a revision of Paradise Lost. The disastrous temptation of the earlier poem is here successfully resisted; its military conflict is here metamorphosed into a conflict of ideas; and Christ's victory in "debelling" (4:605) or pacifying 
Satan after the war in heaven, is here repeated as the gentler, more spiritualized victory of the Lamb's war over the Lion's:

straight a fiery Globe

Of Angels on full sail of wing flew nigh,

Who on their plumy Vans receiv'd him soft

Angelic choirs

Sung Heavenly Anthems of his victory

Over temptation and the Tempter proud.

The poem begins with God's redefinition of heroism and warfare as spiritual and intellectual rather than physical:

By Humiliation and strong Sufferance:

His weakness shall o'ercome Satanic strength

Victory and Triumph to the Son of God

Now ent'ring his great duel, not of arms,

But to vanquish by wisdom hellish wiles.

$(1: 160-75)$

And Christ repudiates his former plan for holy war as a childhood dream:

victorious deeds

Flam'd in my heart, heroic acts; one while

To rescue Israel from the Roman yoke

Then to subdue and quell o'er all the earth

Brute violence and proud Tyrannic pow'r,

Till truth were freed, and equity restor'd:

Yet held it more humane, more heavenly, first

By winning words to conquer willing hearts,

And make persuasion do the work of fear;

At least to try, and teach the erring Soul

Not wilfully misdoing, but unware

Misled.

Book 3 relates Satan's effort to tempt the Son with various attractions of military activity. Christ debunks the appeals to physical prowess, wealth, and fame in a series of anti-war homilies. And after he rebuts Satan's telling point that the Lord of Hosts 
himself cherishes martial glory, the tempter shifts ground to an appeal to duty as a reason for taking up the sword. With clear references to the Army of Saints, he urges Jesus to throw off Tiberius's sacrilegious occupation government of Palestine using the guerrilla war tactics of the Maccabees, who, like the Son, "retir'd unto the Desert, but with arms" (3:166):

If Kingdom move thee not, let move thee Zeal And Duty; Zeal and Duty are not slow, But on Occasion's forelock watchful wait. They themselves rather are occasion best, Zeal of thy Father's house, Duty to free Thy Country from her Heathen servitude.

Satan persists with a loving description of the "martial equipage" of the Parthian army and with a detailed plan for diplomatic treachery that the Son could mobilize to rout the Romans, both of them resembling the aggressive foreign policy options that Milton was privy to as Cromwell's Latin Secretary. This offer provides yet another occasion for rejecting force and fraud:

Much ostentation vain of fleshly arm And fragile arms, much instrument of war Long in preparing, soon to nothing brought, Before mine eyes thou hast set; and in my ear Vented much policy...

that cumbersome

Luggage of war there shown me, argument Of human weakness rather than of strength.

It is particularly germane to the issue of war and peace that Milton chose the Gospel story of the temptation in the wilderness upon which to base his last poem. Religious politics in first century Israel had much in common with those of seventeenth-century England. There was a strong tradition that the coming Messiah would be a military leader who would break the nations with a rod of iron, the lion of Judah who would destroy the power of Rome. The Zealots, who included among their ranks the disciple Simon and quite possibly Judas Iscariot, expected Jesus to raise their flag. When "Jesus took five thousand men into the countryside; it looked like the beginning of a military-political operation, but he gave them a lesson in practical community and sent them away again." 39 
Paradise Regained's affirmation of Quaker pacifist principles seems unmistakable, especially in contrast to the ambiguous politics of the earlier poems. ${ }^{40}$ Rather than an epic or a drama, it reads like a philosophical debate or a platonic dialogue; indeed the identification of truth and virtue is one of its lessons, and Socrates is one of its spokespersons. The poem's hero is a young man in the process of constructing the vision he will leave to the future by confronting and rejecting the wrong choices offered to him by Satan. Unlike the Satan of Paradise Lost, the devil's advocate of this poem is neither malicious, nor cruel. I read in him a projection of the human errors that the old Milton fears he might have made, in particular the error that armed prophets are victorious and the unarmed come to ruin.

\section{NOTES}

${ }^{1}$ Niccolo Machiavelli, The Prince, ed. and trans. Peter Bondanella and Mark Musa (New York: Oxford Univ. Press, 1984), p. 22.

${ }^{2}$ Steven Marx, "Shakespeare's Pacifism," Ren $Q$, in press.

${ }^{3} \mathrm{~A}$ significant connection between Milton and the Quakers has been proposed elsewhere, but to my knowledge, never in terms of pacifist politics. Alden Sampson, Studies in Milton (1913; rpt. edn., New York: AMS Press, 1970) devotes a lengthy chapter (pp. 167-239) to parallels between Milton's views on iconoclasm, humanism, and the "Inner Light" and those of George Fox, the founder of Quakerism.

${ }^{4}$ Columbia: Univ. of Missouri Press, p. 2.

${ }^{5}$ Ithaca: Cornell Univ. Press.

${ }^{6}$ Princeton: Princeton Univ. Press.

${ }^{7}$ New York: Viking Press, 1978, pp. 8-9, 413, 477.

${ }^{8}$ By uniting Scotland and England, by making a treaty between the "natural enemies" of Britain and Spain, and by negotiating an end to hostilities between Sweden and the Hapsburgs.

${ }^{9}$ Louis B. Wright, "Propaganda against James I's 'Appeasement' of Spain," HLQ 6 (1942): 149-171.

${ }^{10}$ Michael Walzer, The Revolution of the Saints: A Study in the Origins of Radical Politics (Cambridge: Harvard Univ. Press, 1965), pp. 285, 287.

${ }^{11}$ Thomas Taylor, Christ's Combat and Conquest (London, 1618), quoted by Walzer, p. 279.

${ }^{12}$ Walzer, p. 269.

${ }^{13} J o h n$ Redingstone, Plain English (London, 1649), p. 3, cited by Roland Bainton, Christian Attitudes toward War and Peace (New York: Abingdon Press, 1960), p. 149.

${ }^{14} A$ Warning-Peece to Warre (London, 1642), cited by Bainton, p. 150.

${ }^{15}$ Thomas Taylor, Christ's Combat and Conquest (London 1618) quoted by Walzer, p. 278. 
${ }^{16}$ This is the argument of Michael Roberts's The Military Revolution, 1500 1660 (Belfast, Ireland: Queens University Press, 1956). See also James A. Aho, Religious Mythology and the Art of War: Comparative Religious Symbolisms of Military Violence (Westport, CT: Greenwood Press, 1981), pp. 194-217.

${ }^{17}$ Bainton, p.157.

${ }^{18}$ Peter Brock, Pacifism in Europe to 1914 (Princeton: Princeton Univ. Press, 1972), pp. 256-57.

19"The Quakers and the English Revolution," Past and Present 10 (November 1956): 39-54. The details of the development of the early peace testimony are complex and somewhat vexed among Quaker historians. Cole's account is based on primary sources and is quoted by Brock on p. 262.

${ }^{20}$ George Fox, The Joumal of George Fox, ed. John L. Nickalls (Cambridge: Cambridge Univ. Press, 1952), p. 65.

${ }^{21}$ Fox, p. 67.

${ }^{22}$ Brock, pp. 260-61.

${ }^{23}$ Fox, p. 198.

${ }^{24}$ Quoted by Bainton, p. 158.

${ }^{25}$ Quoted by William Braithwaite, The Beginnings of Quakerism, 2nd edn. (Cambridge: Cambridge Univ. Press, 1961), p. 484.

${ }^{26}$ Brock, p. 268.

${ }^{27}$ Brock, p. 269.

${ }^{28}$ Hugh Barbour, The Quakers in Puritan England (New Haven: Yale Univ. Press, 1964), pp. 40, 226.

${ }^{29}$ Robert Barclay, An Epistle of Love and Friendly Advice, to the Ambassadors of the Several Princes of Europe (1679), quoted by Brock, p. 274.

${ }^{30} \mathrm{Christopher} \mathrm{Hill,} \mathrm{p.} \mathrm{112,} \mathrm{observes,} \mathrm{"The} \mathrm{curve} \mathrm{of} \mathrm{M.'s} \mathrm{career} \mathrm{quite}$ surprisingly follows that of the Quakers: his support for Cromwell in 1649 and 1653, his growing disillusion under the Protectorate, his rejection of all organized churches, the traumatic effect on him of the Restoration, leading to apparent political quietism and withdrawal from politics whilst still hoping for ultimate divine revenge." The last part of the analogy seems misplaced in reference to the Quakers and depends on the controversial assumption that we take Samson Agonistes as Milton's last poem. It typifies Hill's ideological dismissal of pacifism and his refusal to associate it either with the early Quakers or with Milton. In his many references to connections between Milton and the Quakers, Hill invariably qualifies as "pre-pacifist Quakers." The date of Samson Agonistes is indeterminate-the years 1642, 1647-53, 1660, and 1666-70 have all been proposed by reputable Miltonists-and for that reason, I do not consider the play here. My evidence for Milton's shift from a militaristic to a pacifistic outlook supports a pre-Restoration date for Samson, given the tragedy's Deuteronomic emphasis on Jehovah as a god of warriors whose very existence is questioned by Israelite defeat and whose power is vindicated in the destruction of the Philistine enemy. For discussions of the date of Samson, see Merritt Y. Hughes, John Milton: Complete Poems and Major Prose (New York: Odyssey Press, 1957), pp. 537-42 (All subsequent references to the texts of Milton's poetry are to this edition. Parenthetical references to Paradise Lost and Paradise Regained refer to book and line numbers.); William Riley Parker, Milton: A Biography, 2 vols. (Oxford: Clarendon Press, 1968), pp. 903-17; and Mary Ann Radzinowicz, Toward "Samson Agonistes": The Growth of Milton's Mind (Princeton: Princeton Univ. Press, 1978), pp. 387-407.

31"Areopagitica," ed. Ernest Sirluck, in Complete Prose Works of John Milton, gen. ed. Don M. Wolfe, 8 vols. (New Haven: Yale Univ. Press, 1953-82), 2: 557-58. 
${ }^{32}$ Eikonoklastes, ed. Merritt Y. Hughes, in Complete Prose Works of John Milton, 3: 343-44.

${ }^{334}$ "To the Lord General Cromwell," p. 160.

${ }^{344}$ Considerations Touching the Likeliest means to remove Hirelings Out of the Church," ed. Robert W. Ayers, in Complete Prose Works of John Milton, 7: 274. On the interpretation of this phrase as evidence of Milton's repudiation of Cromwell, see Austin Woolrych, "Milton and Cromwell: "A Short but Scandalous night of Interruption," in Achievements of the Left Hand: Essays on the Prose of John Milton, ed. Michael Lieb and John T. Shawcross (Amherst: Univ. of Massachusetts Press, 1974), pp. 185-219.

${ }^{35}$ Thomas Ellwood, The History of the Life of Thomas Ellwood (London: Methuen, 1900), p. 90.

${ }^{36}$ Ellwood, p. 145.

${ }^{37}$ Ellwood, p. 145.

${ }^{38}$ Parker comments (p. 597): "What the humourless young Quaker failed to realize, in his eager excursion into literary criticism, is that Paradise Lost (at least in its printed version) has a number of very pointed and eloquent things to say of 'paradise found.' We may conjecture, therefore, that the poet's silence was compounded of disappointment and moody self-criticism." It is also possible, however, that Ellwood understood the poem's concluding references to a "paradise within" and sensed that Milton had more to say on the subject.

${ }^{39}$ John Ferguson, War and Peace in the World's Religions (New York: Oxford Univ. Press, 1978), p. 101.

${ }^{40}$ See Hughes's note, Complete Poems, pp. 478-79: "the Christ of Paradise Regained . . . is a figure less like St. Anthony than he is like Ghandi [sic] ... Milton's declaration of the power of 'the Church of God' to rise triumphant over violence. ... Christ's resistance is only in words; and if any supernatural power is used against Satan, it is only the power of truth." 